\title{
Evaluation of Total Phenols, Total Flavonoids and In vitro Antioxidant Activity in the Ethanolic Leaf, Seed and Root Extract of Cajanus cajan (L.) Mill sp
}

\author{
R. Raveena Devi*, R. Premalatha ${ }^{1}$ and R. Kayathri ${ }^{2}$ \\ Department of Microbiology and Biochemistry, Nadar Saraswathi College of Arts and Science, \\ Theni - 625 531, Tamil Nadu, India \\ *Corresponding author email id:
}

\section{Keywords}

Cajanus cajan,

Total Phenols,

Total Flavonoids, Antioxidant potential- DPPH, $\mathrm{H} 2 \mathrm{O} 2$, Total antioxidant capacity.

\section{Article Info}

Accepted:

20 September 2016

Available Online:

10 October 2016

\section{A B S T R A C T}

The purpose of the study was to assess total Flavonoids (TF), total phenols (TP) and antioxidant activity (TAA) in the ethanolic leaf, seed and root extract of Cajanus cajan. Total phenolic content, Total Flavonoids content were measured by using standard procedures and free radical scavenging activities were performed by using DPPH radical scavenging activity, Hydrogen peroxide radical scavenging and phosphomolybdenum assay. The result indicated that total phenolic content in the analysed leaf, seed and root extracts ranged as $55.03 \mathrm{mg} / \mathrm{GAE}$ and $57.20 \mathrm{mg} \backslash \mathrm{GAE}, 50.95 \mathrm{mg} \backslash \mathrm{GAE}$. Similarly Flavonoids content in the analyzed leaf, seed and root extracts ranged as $36.17 \mathrm{mg} \backslash$ RE $\backslash$ gram, $49.43 \mathrm{mg} \backslash \mathrm{RE} \backslash \mathrm{gram}$, and $48.32 \mathrm{mg} \backslash$ RE $/$ gram. The outcome of the antioxidant activity were found to be dosage dependent .The $\mathrm{IC}_{50}$ values for $\mathrm{DPPH}$ assay for ethanolic extract of leaf, seed and root were $1.407,0.844$ and $1.184 \mathrm{mg} \backslash \mathrm{ml}$ respectively. The highest hydroxyl radical scavenging activity reached up to $79.07 \%$ in seed $76.45 \%$ in leaf $75.21 \%$ in root extracts respectively. The highest total antioxidant potentials observed in Cajanus cajan seed extract compared to other extracts. All the assays tested, it was found that the seed extract possessed highest antioxidant activity. These findings indicated that potential antioxidant activity were found in Cajanus cajan leaf, seed and root extracts and needs further exploration for their effective use. The high amount of TFC, TPC, and TAA in the leaf, seed and root of Cajanus cajan, makes Cajanus cajan effective free radical scavenger and a powerful source of natural antioxidants.

\section{Introduction}

Free radicals such as superoxide radical, peroxide radical and hydroxyl radical take part in a vital role in genesis of diverse degenerative diseases (Long et al., 2007). Antioxidants take part in substantial role in inhibiting and scavenging free radicals consequently provided that protection to human against degenerative diseases(Ahmad et al., 2006). Antioxidant derived from exogenous source like synthetic antioxidant 
compounds, such as butylated hydroxyl toluene (BHT) and butylated hydroxyl anisole (BHA) which are habitually used in processed foods, it has been reported that these compounds are responsible for liver damage and carcinogenesis (Ghosh et al., 2009).

So, extensive attention has been paid to antioxidant properties of plant products (fruits, vegetables, medicinal herbs, etc). They reducing oxidative stress -induced tissue injury (Pourmorad et al., 2006). Among the abundant naturally occurring antioxidant; ascorbic acid, carotenoids and phenolic compounds are more effectual to scavenge free radicals and active oxygen species.

Cajanus cajan is one of the diploid legume essential crop species belonging to phaseoleae family. Tropical and subtropical countries are proper places for growing this plant. The morphological features of this plant are especially erect perennial, annual plant having $1-4 \mathrm{~m}$ in height. Cajanus cajan has been used for therapeutic purpose since time immemorial. Its young pods shoot, leaves, and seeds, roots are edible (Raveenadevi et al., 2016).

Diverse pharmacological activities have been endorsed to extracts of parts of the plant, as well as their phytochemical constituents. It mainly contains Flavonoids, isoflavonoid and stilbenes. Flavonoids has antibacterial, antifungal antiviral and anticancer and anti inflammatory effects. Stilbenes are responsible for the beneficial effects of pigeon pea leaves on human health (Luo et al., 2008).

The extract of pigeon pea leaves are generally used to treat wounds, malaria, bedsores, treat against hypoxic-ischemic brain damage and alcohol-induced liver damage and also used as antioxidant, antibacterial and anticancer ability. Their seeds have been found to have antisickling activity (Harish et al., 2014). Cajanol isolated from roots of the plant has been used as novel anticancer agent, which induced apoptosis in human breast cancer cells (king et al., 2010).

The antioxidant activity of the extract of the leaves (Wu et al., 2009) and the hypoglycemic activity of the seed have been reported (Nneka et al., 2016).The isolation of antiplasmodial compounds betulinic acid (roots), longistylin A and C (leaves) from the plant reported (Duker-eshun et al., 2004; Zheng et el., 2007).

There is inadequate information about the biological activities of C.cajan plant. In view of the folk therapeutic uses of the plant as well as various scientific reports, the goal of the current work was aimed to assess total flavonoids, total phenols and antioxidant activity in the ethanolic leaf, seed and root extract of Cajanus cajan

\section{Materials and Methods}

\section{Collection of plant parts}

The fresh leaves, roots and seeds of Cajanus cajan $L$. were simultaneously collected from cultivated farms of Theni district. Fresh parts of the plants were recognized and authenticated prior to studies. The leaves, Seed \& roots were rinsed thrice with distilled water to remove the dust and other contaminants then dried at shade condition for one month. After dry they were grinded into powdered by using a Grinder Machine.

\section{Extraction}

Each powdered sample was extracted separately with $100 \mathrm{ml}$ of ethanol for $3 \mathrm{hrs}$ on 
a magnetic stirrer. The yielded solution was filtered through what man No.1 paper. The concentrated extracts were stored in air tight container refrigerated at $4^{0} \mathrm{c}$ for the further tests.

\section{Determination of total phenolic content}

Total phenolic content of the leaf, seed and root extracts of C.cajan was determined using the Folin-cio Calteau reagent. Folin diluted 10 times with distilled water. Ethanolic extract of leaf, seed and root extracts solutions $(50 \mu \mathrm{l})$ was mixed with $1 \mathrm{ml}$ diluted Folin-cio Calteau reagent, $1 \mathrm{ml}$ sodium bicarbonate solution $(7.5 \%)$ and $2 \mathrm{ml}$ distilled water. The mixture was incubated at room temperature for $15 \mathrm{~min}$. The absorbance of the solution was determined at 730nm using spectrometer and compared with Gallic acid equivalents calibration curve. The total phenolic content was expressed as mg Gallic acid equivalents of C.cajan.

\section{Determination of total Flavonoids content}

Total flavonoids content of the leaf, seed and root extracts of C.cajan was determined according to the aluminium chloride method. In brief, $50 \mu 1$ of leaf, seed and root extract were mixed with $4 \mathrm{ml}$ of distilled water and $0.3 \mathrm{ml}$ of $5 \% \mathrm{NaNO}_{2}$ solution, $0.3 \mathrm{ml}$ of $10 \% \mathrm{AlCl}_{3}$ solution was added after 5 minutes of incubation, and the mixture was allowed to stand for 6 minutes. Then $2 \mathrm{ml}$ of 1 molvitter $\mathrm{NAOH}$ solution were added and the final volume of the mixture was brought to $10 \mathrm{ml}$ of double distilled water. The mixture was allowed to stand for 15 minutes and absorbance was measured at 510nm. The total Flavonoids content was calculated from a calibration curve and the result expressed as mg rutin equivalent per gram dry weight.

\section{In vitro antioxidant activity evaluation}

\section{DPPH Radicals Scavenging Potentials}

DPPH Scavenging activity of ethanolic extract was carried out by Blois 1958 .

Cajanus cajan ethanol extract (leaf, seed\& root) was mixed with methanol and it was kept under incubation for $24 \mathrm{hrs}$.the sample was centrifuged at $1200 \mathrm{rpm}$ for 10 minutes and the methanol supernatant was taken for the antioxidant activity studies.

Different concentration of $(200-800 \mu \mathrm{g} / \mathrm{ml})$ solvent extracts and ascorbic acid was prepared in methanol to this $3 \mathrm{ml}$ of the extract, $1 \mathrm{ml}$ of DPPH solution was added. The reaction mixture was mixed well and incubated at room temperature for 30minutes. After incubation, absorbance was read at 570nm. Ascorbic acid used as a reference compound. The capacity to scavenge the DPPH radical was calculated using the following equations.

The $\%$ inhibition was calculated as,

$\% \mathrm{DPPH}$ scavenging activity $=(\mathrm{A}$ control-A test $) \backslash($ A control $\times 100)$

Where a control is the absorbance of the control reaction and A test is the absorbance of the extract. The antioxidant activity of the extract was expressed as IC 50. The IC 50 value is defined as the concentration in $\mu \mathrm{g} / \mathrm{ml}$ of extract that inhibits the formation of DPPH radical by \%

\section{Total antioxidant capacity test}

Antioxidant activity of the extract was evaluated by the phosphomolybdenum method according to the procedure described in Prieto et al., 1999. 
A 3ml of extract (Leaf, seed \&root) was combined with $3 \mathrm{ml}$ of reagent solution $(0.6 \mathrm{~m}$ sulphuric acid, $28 \mathrm{Mm}$ sodium phosphate and $4 \mathrm{Mm}$ ammonium molybdate). The tubes containing the reaction solution were incubated at $95^{\circ} \mathrm{C}$ for $90 \mathrm{~min}$. Then absorbance of the solution was measured at $695 \mathrm{~nm}$ using a spectrophotometer against blank after cooling to room temperature. Ethanol $(0.3 \mathrm{ml})$ extract used as the blank. The antioxidant activity is expressed as the number of gram equivalents of ascorbic acid.

\section{Hydroxyl radical scavenging activity}

The $\mathrm{H}_{2} \mathrm{O}_{2}$ radical scavenging activity of ethanolic extract was determined by Ruch et al., 1989.

\section{Procedure}

Leaf, seed \&root extracts of various concentrations were prepared (200$800 \mu \mathrm{g} / \mathrm{ml}$ ) in distilled water. $1 \mathrm{ml}$ of various concentration of extract was taken in series of test tubes. To each tube $0.6 \mathrm{ml}$ of $40 \mathrm{mM}$ $\mathrm{H}_{2} \mathrm{O}_{2}$ solution was added and incubated for 10minutes in room temperature. The absorbance of sample was read at $230 \mathrm{~nm}$ against a blank solution containing the phosphate buffer without $\mathrm{H}_{2} \mathrm{O}_{2}$.ascorbic acid was used as a standard antioxidant.

The $\%$ inhibition was calculated as,

$\% \mathrm{H}_{2} \mathrm{O}_{2}$ scavenging activity $=(\mathrm{A}$ control- $\mathrm{A}$ test) $\backslash$ (A control $\times 100)$

Where a control is the absorbance of the control reaction and A test is the absorbance of the extract. The antioxidant activity of the extract was expressed as IC 50. The IC 50 valve is defined as the concentration in $\mu \mathrm{g} / \mathrm{ml}$ of extract that inhibits the formation of radical by $\%$.

\section{Statistical Analysis}

Mean value of phenols $\mathrm{mg} / \mathrm{g}$ Dry Weight and Flavonoids mg/g Dry Weight were compared using independent t-test. Comparison of anti-oxidant properties of Ascorbic acid, Cajanus cajan, different antioxidant Assay was done using one way analysis of variance (ANOVA). P-value less than 0.5 were considered statistically significant.

\section{Result and Discussion}

\section{Total phenolic content}

Total phenolic content of ethanolic extract of leaf, seed and root of Cajanus cajan was evaluated by using the Folin-ciocalteu colorimetric method. The phenolic content in the analysed leaf, seed and root extracts ranged as $55.03 \mathrm{mg} \backslash \mathrm{GAE}$ and $57.20 \mathrm{mg} \backslash \mathrm{GAE}$, $50.95 \mathrm{mg} \backslash \mathrm{GAE}$ (Table 1) .The highest content of phenols was assessed in Cajanus cajan seed extract when compared to leaf and root extracts. Phenolic compounds have redox properties which allow them to act as antioxidant (Mahitha et al., 2015).As their free radical scavenging ability is facilitated by their $\mathrm{OH}$ groups, the total phenolic concentration could be used as a basis for rapid screening of antioxidant activity.

\section{Total Flavonoids Content}

The presence of Flavonoids content in analysed leaf, seed and root ethanolic extracts of C.cajan ranged as 36.17 mg\RE Igram, $49.43 \quad \mathrm{mg} \backslash \mathrm{RE} \backslash \mathrm{gram}$, $48.32 \mathrm{mg} \backslash$ RE $\backslash$ gram (Table 1).The highest content of Flavonoids was found in seed extracts while, leaf and root extracts have lowest Flavonoids content was assessed.

\section{Antioxidant Assay}

The antioxidant activity of ethanol extract of leaves, seeds and roots of Cajanus cajan 
were investigated. The leaf, seed and root extract of Cajanus cajan was able to scavenge the free radicals in different concentration in a dose dependent manner in all the assays.

\section{DPPH Assay}

DPPH, relatively stable organic radical with a typical strong absorption band at $517 \mathrm{~nm}$ invisible spectroscopy (deep violet colour) was used to evaluate the free radical scavenging capacity of the investigated samples. Ascorbic acid used as positive control for standard. Among the extracts tested, the seeds extract exhibited better activity. The $\mathrm{IC}_{50}$ valves for leaves, seeds and roots extracts were 1.407, 0.844 and $1.184 \mathrm{mg} \backslash \mathrm{ml}$ respectively (Table 11 ). When the concentrations were lower the DPPH radical scavenging activity of leaves and roots extracts were weak, when the concentration was higher their activity much enhanced. The effect of antioxidants on DPPH radical scavenging was thought to be due to their hydrogen donating ability. Interestingly these values were significantly lower than the standard antioxidant tested. Our results are contradiction with Maneechai et al., (2011).who reported that highest antioxidant activity was examined in ethanolic seed extracts by DPPH assay.

Table.1 Total Phenolic and Total Flavonoids content of C.cajan extracts

\begin{tabular}{|l|l|l|}
\hline $\begin{array}{l}\text { Different ethanolic } \\
\text { extract }\end{array}$ & $\begin{array}{l}\text { Total Phenols(mg of GAElg of } \\
\text { extract) }\end{array}$ & $\begin{array}{l}\text { Total Flavonoids(mgQElg } \\
\text { extract) }\end{array}$ \\
\hline Leaf & 55.03 & 36.17 \\
\hline Seed & 57.20 & 49.43 \\
\hline Root & 50.95 & 48.32 \\
\hline
\end{tabular}

Table.2 Invitro DPPH Scavenging activity of C.cajan leaf extract

\begin{tabular}{|l|l|l|l|}
\hline \multicolumn{4}{|c|}{$\begin{array}{c}\text { DPPH Scavenging Activity } \\
(\% \text { INHIBITION })\end{array}$} \\
\hline S.NO & $\begin{array}{l}\text { Concentration } \\
(\boldsymbol{\mu g} / \mathrm{ml})\end{array}$ & $\begin{array}{l}\text { LEAF } \\
(\%)\end{array}$ & $\begin{array}{l}\text { Ascorbic } \\
\text { acid (\%) }\end{array}$ \\
\hline 1 & 200 & 42.11 & 64.66 \\
\hline 2 & 400 & 55.2 & 67.91 \\
\hline 3 & 600 & 64.56 & 73.26 \\
\hline 4 & 800 & 69.83 & 78.09 \\
\hline
\end{tabular}

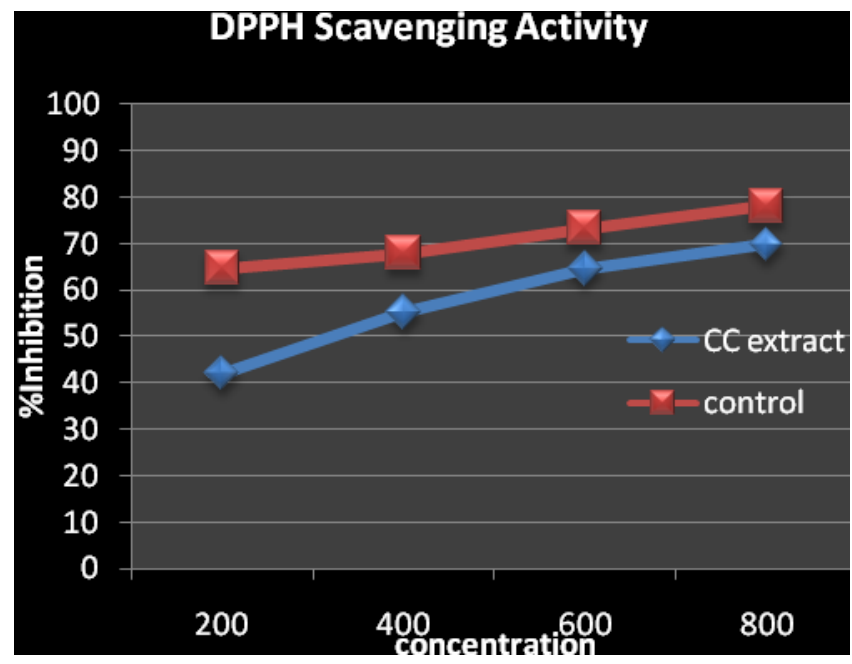


Table.3 Total antioxidant activity of C.cajan leaf extract

\begin{tabular}{|l|l|l|l|}
\hline \multicolumn{4}{|c|}{$\begin{array}{c}\text { Total antioxidant activity } \\
(\% \text { INHIBITION })\end{array}$} \\
\hline S.NO & $\begin{array}{l}\text { Concentration } \\
(\boldsymbol{\mu g} / \mathbf{m l})\end{array}$ & $\begin{array}{l}\text { LEAF } \\
(\boldsymbol{\%})\end{array}$ & $\begin{array}{l}\text { Ascorbic } \\
\text { acid }(\boldsymbol{\%})\end{array}$ \\
\hline 1 & 200 & 49.13 & 55.02 \\
\hline 2 & 400 & 52.72 & 63.90 \\
\hline 3 & 600 & 61.69 & 69.02 \\
\hline 4 & 800 & 64.09 & 74.04 \\
\hline
\end{tabular}

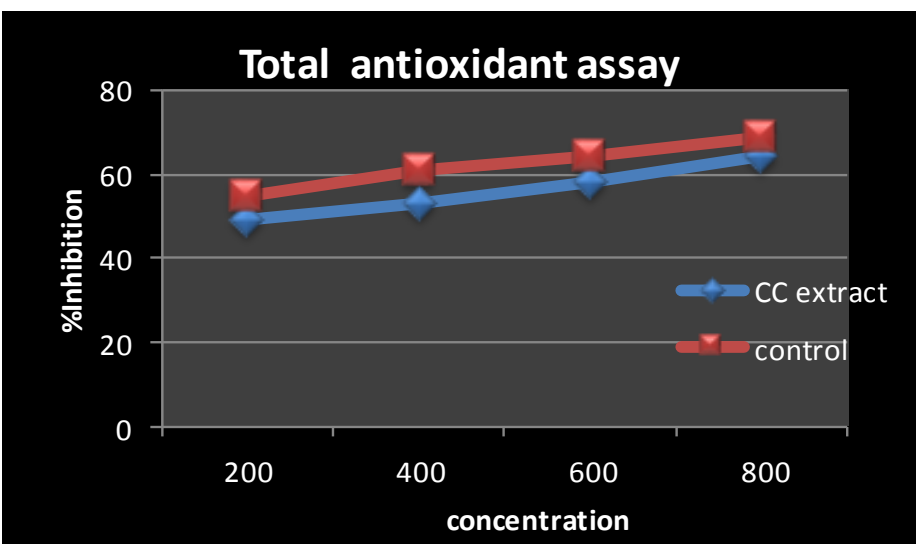

Table. $4 \mathrm{H}_{2} \mathrm{O}_{2}$ Radical assay of C.cajan leaf extract

\begin{tabular}{|l|l|l|l|}
\hline \multicolumn{4}{|c|}{$\begin{array}{c}\mathbf{H}_{2} \mathbf{O}_{2} \text { Radical assay } \\
(\% \text { INHIBITION })\end{array}$} \\
\hline S.NO & $\begin{array}{l}\text { Concentration } \\
(\boldsymbol{\mu g} / \mathbf{m l})\end{array}$ & $\begin{array}{l}\text { LEAF } \\
(\boldsymbol{\%})\end{array}$ & $\begin{array}{l}\text { Ascorbic } \\
\text { acid (\%) }\end{array}$ \\
\hline 1 & 200 & 60.04 & 64.34 \\
\hline 2 & 400 & 63.05 & 68.54 \\
\hline 3 & 600 & 67.87 & 75.43 \\
\hline 4 & 800 & 76.45 & 79.39 \\
\hline
\end{tabular}

Table.5 Invitro dpph scavenging of C.cajan seed extract

\begin{tabular}{|l|l|l|l|}
\hline \multicolumn{4}{|c|}{$\begin{array}{c}\text { DPPH scavenging activity } \\
(\% \text { INHIBION })\end{array}$} \\
\hline S.NO & $\begin{array}{c}\text { Concentration } \\
(\boldsymbol{\mu g} / \mathbf{m l})\end{array}$ & $\begin{array}{l}\text { Cc Seed } \\
\text { extract }\end{array}$ & $\begin{array}{l}\text { Ascorbic } \\
\text { acid }\end{array}$ \\
\hline 1. & 200 & 46.6 & 52.82 \\
\hline 2. & 400 & 57.2 & 64.25 \\
\hline 3. & 600 & 67.8 & 74.78 \\
\hline 4. & 800 & 74.3 & 80.56 \\
\hline
\end{tabular}

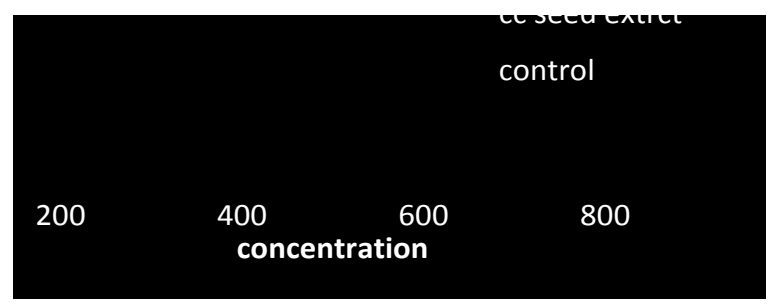


Table.6 Total antioxidant activity of C.cajan seed extract

\begin{tabular}{|l|l|l|l|}
\hline \multicolumn{4}{|c|}{$\begin{array}{c}\text { Total antioxidant activity } \\
(\% \text { INHIBITION })\end{array}$} \\
\hline S.NO & $\begin{array}{l}\text { Concentration } \\
(\boldsymbol{\mu g} / \mathbf{m l})\end{array}$ & $\begin{array}{l}\text { Cc seed } \\
\text { Extract }\end{array}$ & $\begin{array}{l}\text { Ascorbic } \\
\text { acid }\end{array}$ \\
\hline 1. & 200 & 47.2 & 53.02 \\
\hline 2. & 400 & 54.6 & 59.12 \\
\hline 3. & 600 & 62.2 & 70.56 \\
\hline 4. & 800 & 70.2 & 74.5 \\
\hline
\end{tabular}

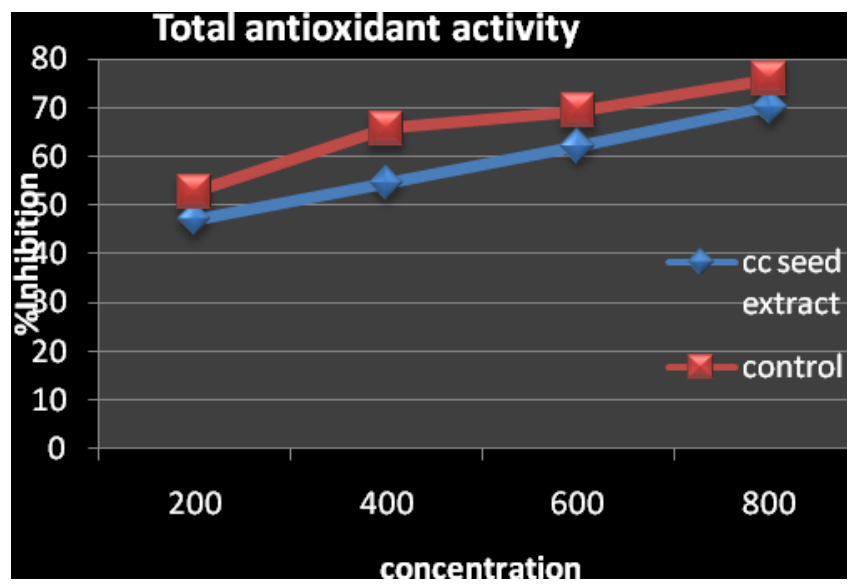

Table.7 $\mathrm{H}_{2} \mathrm{O}_{2}$ Radical assay of C.cajan seed extract

\begin{tabular}{|l|l|l|l|}
\hline \multicolumn{4}{|c|}{$\begin{array}{c}\mathbf{H}_{2} \mathbf{O}_{2} \text { Radical assay } \\
(\% \text { INHIBITION })\end{array}$} \\
\hline S.NO & $\begin{array}{l}\text { Concentration } \\
(\boldsymbol{\mu g} / \mathbf{m l})\end{array}$ & $\begin{array}{l}\text { Cc Seed } \\
\text { extract }\end{array}$ & Ascorbic acid \\
\hline 1. & 200 & 62.72 & 65.06 \\
\hline 2. & 400 & 66.32 & 69.89 \\
\hline 3. & 600 & 75.20 & 79.43 \\
\hline 4. & 800 & 79.07 & 83.98 \\
\hline
\end{tabular}

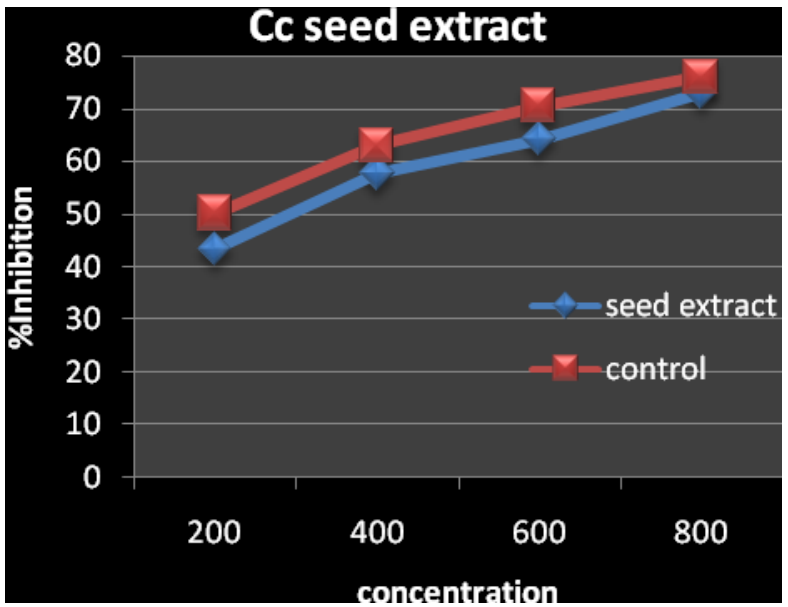

Table.8 Invitro DPPH scavenging activity of C.cajan root extract

\begin{tabular}{|l|l|l|l|}
\hline \multicolumn{4}{|c|}{$\begin{array}{c}\text { DPPH Scavenging Activity } \\
(\% \text { INHIBITION ) }\end{array}$} \\
\hline S.NO & $\begin{array}{c}\text { Concentration } \\
(\mu \mathrm{g} / \mathrm{ml})\end{array}$ & $\begin{array}{l}\text { Cc root } \\
\text { extract }(\%)\end{array}$ & $\begin{array}{l}\text { Ascorbic } \\
\text { acid }\end{array}$ \\
\hline 1 & 200 & 43.07 & 49.90 \\
\hline 2 & 400 & 56.08 & 60.45 \\
\hline 3 & 600 & 63.65 & 69.45 \\
\hline 4 & 800 & 71.48 & 76.89 \\
\hline
\end{tabular}

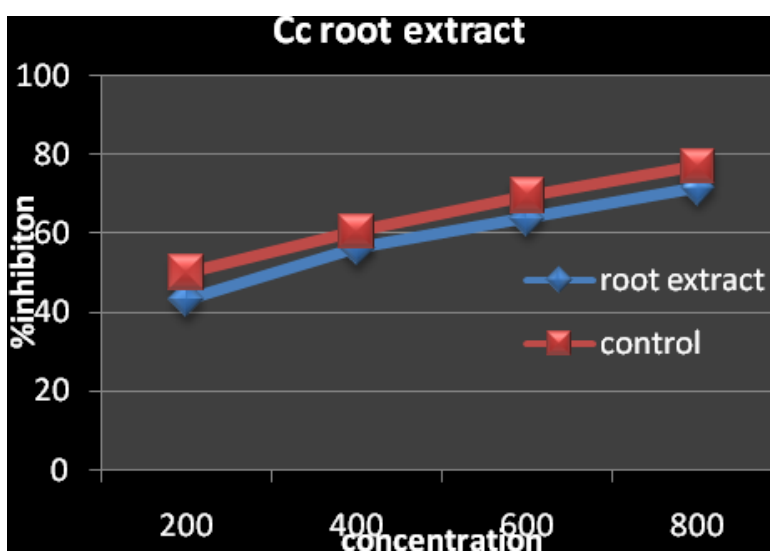


Table.9 Total antioxidant activity of C.cajan root extract

\begin{tabular}{|l|l|l|l|}
\hline \multicolumn{4}{|c|}{$\begin{array}{l}\text { Total antioxidant activity } \\
(\% \text { INHIBITION) }\end{array}$} \\
\hline S.NO & $\begin{array}{l}\text { Concentration } \\
(\boldsymbol{\mu g} / \mathbf{m l})\end{array}$ & $\begin{array}{l}\text { Cc ROOT } \\
\text { extract } \\
(\%)\end{array}$ & $\begin{array}{l}\text { Ascorbic } \\
\text { acid }\end{array}$ \\
\hline 1 & 200 & 45.53 & 53.98 \\
\hline 2 & 400 & 52.82 & 58.56 \\
\hline 3 & 600 & 58.82 & 67.93 \\
\hline 4 & 800 & 69.32 & 75.86 \\
\hline
\end{tabular}

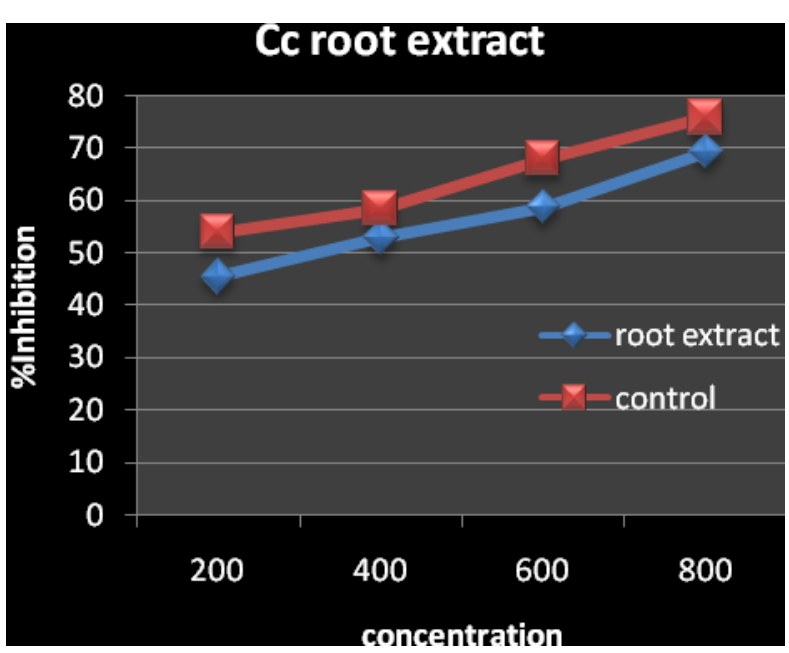

Table.10 $\mathrm{H}_{2} \mathrm{O}_{2}$ radical assays of C.cajan root extract

\begin{tabular}{|l|l|l|l|}
\hline \multicolumn{4}{|c|}{$\begin{array}{l}\mathbf{H}_{2} \mathbf{O}_{\mathbf{2}} \text { Radical assays } \\
(\mathbf{\%} \text { INHIBITION })\end{array}$} \\
\hline S. NO & $\begin{array}{l}\text { Concentration } \\
(\boldsymbol{\mu g} / \mathbf{m l})\end{array}$ & $\begin{array}{l}\text { Cc ROOT } \\
\text { extract } \\
(\boldsymbol{\%})\end{array}$ & $\begin{array}{l}\text { Ascor } \\
\text { bic } \\
\text { acid }\end{array}$ \\
\hline 1 & 200 & 59.99 & 64.71 \\
\hline 2 & 400 & 65.05 & 69.01 \\
\hline 3 & 600 & 72.12 & 75.90 \\
\hline 4 & 800 & 75.21 & 80.40 \\
\hline
\end{tabular}

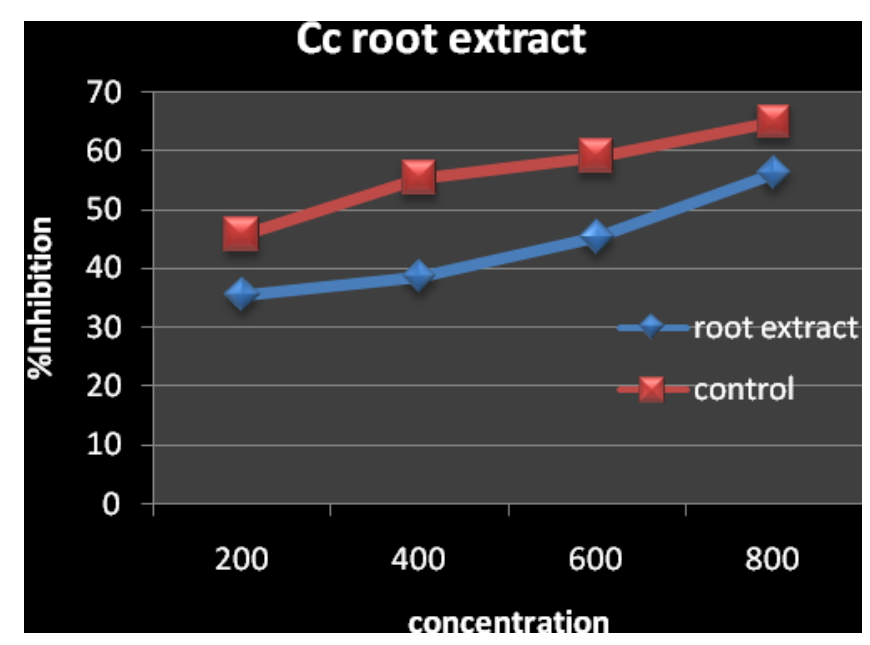

Table.11

\begin{tabular}{|c|c|}
\hline \multicolumn{2}{|c|}{ IC $_{50}$ for DPPH activity Cajanus cajan } \\
\hline Leaf & 1.407 \\
\hline seed & 0.844 \\
\hline Root & 1.184 \\
\hline
\end{tabular}

Table.12

\begin{tabular}{|c|c|}
\hline \multicolumn{2}{|c|}{$\mathrm{IC}_{50}$ for $\mathrm{H}_{2} \mathrm{O}_{2}$ activity } \\
\hline Leaf & 2.6 \\
\hline seed & 2.4 \\
\hline Root & 2.5 \\
\hline
\end{tabular}




\section{Total Antioxidant Capacity}

To assess the total antioxidant capacity by phosphomolybdenum assay .The data on total antioxidant capacity observed in leaf, seed root extract of Cajanus cajan (fig).The antioxidant activity of phosphomolybdenum assay was found in the order seed $>$ leaf $>$ root. Among the extracts tested seed extracts showed highest antioxidant activity in comparison to others. The Result of the study are in conformity with the reports of Muhammad Jahangir et al., (2014).They have reported that Cajanus cajan seeds exhibited the high antioxidant capacity in polar and non -polar fractions.

\section{$\mathrm{H}_{2} \mathrm{O}_{2}$ scavenging activity}

The hydroxyl radical scavenging activity of leaf, seed and root extracts of Cajanus cajan in various concentration $(200,400,800$ ug $\backslash \mathrm{ml})$ tested. The scavenging activity was found to be $62.72 \%, 66.32 \% 75.20 \%$ and $79.07 \%$ in seed and $60.04 \%, 63.05 \%$, $67.87 \%$ and $76.45 \%$ in leaf and $59.99 \%$, $65.05 \%, 72.12 \%$ and $75.21 \%$ in root extracts respectively. The IC 50 values of seed and leaf, root extracts were found to be 2.4 $\mu \mathrm{g} \backslash \mathrm{ml}, 2.6 \mu \mathrm{g} \backslash \mathrm{ml}$ and $2.5 \mu \mathrm{g} \backslash \mathrm{ml}$ respectively (Table 12).In this activity ethanol extracts of C.cajan increased in dose dependent manner. Similarly, good hydroxyl radical scavenging activity was also reported in legume seed extracts. In the present study C.cajan seed extracts can be considered as good scavengers of hydroxyl radicals. $\mathrm{H}_{2} \mathrm{O}_{2}$ is relatively stable in the absence of reducing compounds. Scavenging of $\mathrm{H}_{2} \mathrm{O}_{2}$ by Cajanus cajan (leaf, seed, root) may be attributed for electrons donating abilities (wettasinge et al., 2000).

In conclusion, the current study clearly stated that leaf, seed and root extract of Cajanus cajan posses a high amount of total flavonoids as well as total phenolics making it a good source of natural antioxidants. The natural antioxidants that might be helpful in preventing various oxidative stress related disease, as ethanomedicine and also for creation of green drug commercially.

\section{Acknowledgements}

The project was supported by laboratory of Department of Microbiology \& Biochemistry in Nadar Saraswathi College of Arts \& Science, Theni. I thank the Management, Principal, Head of the Department, Faculty members for their guidance and support.

\section{References}

Ahmad, I., Aqil, F., Mehmood, Z. 2006. antioxidant and free radical scavenging properties of twelve traditionally used Indian medicinal plants. Turk. J. Biol., 30: 177-183.

Blois, M. 1958. Antioxidant Determinations by the Use of a Stable Free Radical. Nature, 181: 1199-1200.

Duker -Eshun, G., Jaroszewski, J.W., Asomaning, W.A., Oppong-Boachie, F. and Christensen, S.B. 2004. Antiplasmodial Constituents Of Cajanus cajan. Phytother Res., 18: 128-130.

Ghosh, T., Maity, T.K., Bose, A. 2009. Invitro free radical scavenging activity of ethanolic extract of leaves of Cajanus Cajan (L.)Mill sp. J. Nat. Rem., 9(2):228-234.

Grover, J.K., Yadav, S. and Vats, V.J. 2002. Medicinal Plants of India with Ant Diabetic Potential. J. Ethnopharmacol., 81: 81-100

King, Y., Fu, Y.J., Zu, Y.G., Chang, F.R., Chen, Y.H., Liu, X.L. 2010. Cajanus lactone A New Coumarin with AntiBacterial Activity from Pigeon Pea Leaves. Food Chem., 121: 11505.

Long, L.H., Chua, D.T.K., Halliwell, B. 2007. The antioxidant activities of seasonings 
used in Asian cooking. Powerful antioxidant activity of dark soy sauce revealed using the ABTS Assay. Free Radical Biol. Med., 32: 181-186.

Luo, Q.F., Sun, L., Si, J.Y., Chen, D.H. 2008. Hypocholesterolaemia Effect of Stilbenes Containing Extract Fraction from Cajanus cajan On Diet Induced Hypercholesterolemia In Mice. Phytomed., 15: 932-9.

Mahitha, B., Archana, P., Ebrahimzadeh, M.D.H., Srikanth, K., Rajinikanth, M., Ramaswamy, N. 2015. Invitro antioxidant and pharmacognostic studies of leaf extracts of Cajanus cajan(L.)Mill sp. Indian Journal of Pharmaceutical Sciences, 77: 170-177.

Meenasahi, Devshreeverma and K.K. Harris. 2014. Phytochemical analysis Of The Leaf, Stem And Seed Extracts Of Cajanus cajan L(Dicotyledoneae: Fabaceae, World J. Pharm. Pharma. Sci., Volume 3, Issue 8, 694-733.

Mugammedjahagir, Raisakanum, Farhanamazhar. 2015. Antioxidant evolution of Polar and Non Polar Fractions of Cajanus cajan Seeds. J. Med. Plants Res., Vol.9 (6), 193-198.

Nneka, N., Vchegbu charies, N., Ishiwu 2016. Germinated pigeon pea (Cajanus cajan) a novel diet for lowering oxidative stress and hyperglycaemia. Food sci. Nutrition, volume 4, Issue 5.

Pourmorad, F., Hosseinimehr, S.J., Shabimajd, N. 2006. antioxidant activity, phenols, flavonoids contents of selected Iranian medicinal plants. S. Afr. J. Biotechnol., 5: 1142-1145.
Prieto, P., Pineda, M., Aguilar, M. 1999. Spectroohotometric Quantification of Antioxidant Capacity through the Formation a Phosphomolybdenum Complex; Specific Application of Vitamin E. Anal. Biochem., 269: 337341.

Raveena Devi, R., Premalatha, .R, Saranya, A. 2016. Comparative analysis of phytochemical constituents and antibacterial activity of leaf, seed and root extract of Cajanus cajan (L.)Mill sp Int. J. Curr. Microbiol. App. Sci., 5(3): 485-494.

Ruch, R.J., Cheng, S.J., Klauing, J.F. 1989. Prevention Of Cytotoxicity And Inhibition Of Intracellular Communication By Antioxidant Catechins Isolated From Chinesh Green Tea.Carcinogenesis, 10: 1003-1008.

Wettasinge, M., Shahidi, F. 2000. Scavenging of reactive species and DPPH free radicals by extracts of borage and evening primrose meals. Food chem., 70: 17-26.

Wu, N., Fu, K., Fu, Y.J., Zu, Y.G., Chang, F.R., Chen, Y.H. 2009. Antioxidant Activities Of Extracts And Main Components Of Pigeon Pea Leaves. Mol., 14: 1032-43.

Zheng, Y.Y., Yang, J., Chen, D.H. and Sun, L. 2007. Effects of the stilbenes extracts from Cajanus cajan L. on ovariectomyinduced bone loss in rats. Acta pharm. Sin, 42: 562-565.

\section{How to cite this article:}

Raveena Devi, R., R. Premalatha and Kayathri, R. 2016. Evaluation of Total Phenols, Total Flavonoids and In vitro Antioxidant Activity in the Ethanolic Leaf, Seed and Root Extract of Cajanus cajan (L.) Mill sp. Int.J.Curr.Microbiol.App.Sci. 5(10): 688-697.

doi: http://dx.doi.org/10.20546/ijcmas.2016.510.075 